\title{
Community Health Agent: a professional world in search of consolidation
}

\author{
$1{ }^{1}$ Carolina Maria do Carmo Alonso, 2 Pascal Daniel Béguin, ${ }^{3}$ Valérie Pueyo, \\ ${ }^{4}$ Francisco José de Castro Moura Duarte I
}

Abstract: The contribution of community health agents (CHAs) is strategic for overcoming the biomedical health model. However, weaknesses in defining the specific roles of this profession impose contradictions and impediments to this work, making it difficult to construct the professional world of CHAs. Thus, this study aimed to analyze the tasks performed by the CHAs to reveal the objects, values, and tools, used by these workers to help consolidate their professional world. This study is a qualitative research study guided by the principles of activity ergonomics that include documentary analysis, systematic observations, and interviews. The results showed that due to the myriad of activities performed by the CHAs, the professional world of these workers is not fully delineated. However, it is believed that the results, analysis, and discussion of the data verified in this research, can support the consolidation of the professional world of the CHAs.

> Keywords: Ergonomics; Primary Health Care; multiprofessional teamwork.

\author{
${ }^{1}$ Terapia Ocupacional, Faculdade \\ de Medicina, Universidade Federal \\ do Rio de Janeiro. Rio de Janeiro- \\ RJ, Brazil (carolina.alonso@ \\ medicina.ufrj.br). \\ ORCID: 0000-0003-4928-4465 \\ 2 Institut D'Etudes du Travail Lyon, \\ Université Lumière Lyon 2. Lyon, \\ France (pascal.daniel.beguin@ \\ gmail.com). \\ ORCID: 0000-0002-2914-6113 \\ ${ }^{3}$ Institut D'Etudes du Travail Lyon, \\ Université Lumière Lyon 2. Lyon, \\ France (valerie.pueyo@gmail.com). \\ ORCID: 0000-0002-9626-0805 \\ ${ }^{4}$ Programa de Engenharia de \\ Produção COPPE, Universidade \\ Federal do Rio de Janeiro. Rio de \\ Janeiro-RJ, Brazil (fjcmduarte@ \\ gmail.com). \\ ORCID: 0000-0001-9178-3458
}

Received: 07/02/2020 Approved: $17 / 11 / 2020$ Revised: 29/03/2021 


\section{Introduction}

This article highlights the work of community health agents (CHAs), whose contribution is seen as strategic in overcoming the biomedical model of health challenges, since their activities can be focused by political and social factors (CORIOLANO; LIMA, 2010; SAKATA; MISHIMA, 2012; BINDA; BIANCO; SOUSA, 2013; ALONSO, 2017). This potency of the work of CHA is because they do not have a rigid set of theoretical technical standards and guidelines, compared with the historical knowledge defining other health professionals, such as doctors and nurses (BARRALAS; PEREIRA, 2011).

However, Tomaz (2002) points out that there is no clear definition of this profession, with two separate trends existing: the first romanticizes the CHA's duties yet neglects the difficulties and limitations of their practices; the second considers them superheroes as though responsible for consolidating the proposals of the Unified Health System (UHS) without considering technical, political, and social factors, also necessary for this to happen.

In addition, diverse roles are allocated to CHAs, ranging from educators, mediators, interpreters, supporters of family health teams, and supporters of social movements in the community (ARRUDA et al., 2010; BARALHAS; PEREIRA, 2011; GALAVOTE et al., 2013; OLIVEIRA et al., 2012). It is also noteworthy that the main characteristic of the CHA's work is to be a link between the community and the health services. This creates a duality in their work environment, requiring a continuous transition between two universes. The lack of clearly defined scope of the CHA's work requirements, facilitates constant innovation be incorporated to navigate within the health field. At the same time, it also places them at a crossroads between the normative provisions and the challenges faced within this terrain. In this context, as the CHA's activities has not been fully structured yet, issues relating to professional identity emerge in the way tasks are conceptualized and performed (ALONSO, 2017).

As the CHA's work is located at the intersection of different professional disciplines, they are more prone to contradictions and impediments in the performance of their activities. Therefore, this article aims to analyze the tasks performed by the $\mathrm{CHA}$ to reveal the object, values, and tools, used by these workers to help consolidate their professional world. 


\section{The concept of professional worlds}

According to Béguin (2007), the need to integrate different points of view in a project, as well as in a given health care situation, creates additional complexity to the work process. Whatever the project is to be conceived, it cannot be conceptualized by overlapping different technical systems. Therefore, it will always be necessary to integrate the different views concerning a work objective in a coherent and coordinated manner (BÉGUIN, 2007; ALONSO, 2017).

To analyze this integration of knowledge in a multi-professional teamwork situation, Béguin $(2007,2010)$ introduced the concepts of the professional world and the common world on the foundation of work sociology. In this field, the definition of the world is used to designate sociological entities, for instance the civic, and market worlds.

To work is to inhabit a world and, in each situation, a worker engenders ways of thinking, of doing, of living, by mobilizing a system of professional coordinates that allows him to trace his paths. Therefore, it is these ways of understanding the work to be done and navigating this coordinate system, which Béguin (2010) calls the professional worlds.

In this context, faced with the same work situation, various professional worlds are possible (BÉGUIN, 2010). This diversity was illustrated by Bucciarelli (1994), who examined the work of designers and demonstrated that an object can be analyzed in different ways. For example, a designer would refer to a certain object as an emergency stop button, while the engineer identifies the same object as a trunk button.

The term professional world is defined by Béguin $(2007,2010)$ as a set of implicit, conceptual, and practical values that forms a system with the object of the action. Based on this concept, the author established a category for analysis of the activity that focuses on the relationship between the worker and the work situation, based on the idea that the worker is an actor, and not a spectator in this relationship. Consequently, the professional world concept features the background that guides the interpretation of the tangible dimension of action that permits the worker to build unique strategies to achieve a certain goal (BÉGUIN, 2010).

The objective of a professional world is organizing systems, solving problems using abilities, skills, and strategies, to avoid staying on the sidelines of the event. To be a specialist is to have a particular skillset, but also to build a more integrated 
professional world. Thus, the creation of a common world enables the possibility of mutual learning and coordination among different professional worlds (BÉGUIN, 2010). Even though doctors and CHAs share the same territory, working with the same patients, two different worlds are at play. The common operating framework that is either built, or not built, between doctors and CHAs is therefore conditioned by the shape and nature of relationships established between these two worlds. This opens an array of possibilities in which these interactions are either fecund and flexible, or non-existent and rigid.

According to Béguin $(2007,2010)$, the dialog between different professional worlds locates the relative positions and their reciprocal influences, referred to as its cartography. Although there is an interdependence between the constructs within these two worlds, this article focuses specifically on analyzing the concept of the professional world.

\section{The theoretical and methodological pathway}

This study ${ }^{1}$ performed qualitative research based on principles of the methodological approach to activity ergonomics (AE) proposed by Guérin and colleagues (2001) as follows: a) demand analysis; b) analysis of the organizational, technical, economic, and social environment; c) task analysis; d) analysis of activities and work situations; and e) study validation with workers, and formulating recommendations for work transformations. The data collection period was between January 2014 and April 2015 at a health unit located in the northern area of Rio de Janeiro, with four family health teams.

In this manuscript, the results are related to the phases: analysis of the organizational, technical, economic, and social environment, and task analysis. The participants in this phase of the study were primarily CHA; however, other service actors were also included as key informants. Data were obtained through interviews and observations. The procedures for collecting and analyzing these data are detailed in the following sections.

\section{Analysis of the CHA work prescriptions}

This analysis aimed to examine the prescribed work of $\mathrm{CHAs}$, together with the technical and social environment of the service. In this sense, the aim is to weave together mutual considerations of prescribed work, as adopted by the AE. 
Within the AE, prescribed work means "the way the work must be performed: how to use the tools and machines, the time allotted for each operation, the operating methods, and procedures to be followed" (DANIELLOU; LAVILLE; TEIGER, 1989, p. 1). Work prescriptions are important in this discipline, since interventions, based on this approach, aim to identify the gap between the prescribed and actual work situations (BRITO et al., 2011; NOUROUDINE, 2011). Thus, one of the contributions of $\mathrm{AE}$ is to highlight that work is not just executed prescriptions but in reality, presents with variables. On the other hand, as $\mathrm{AE}$ states that prescriptions are references to guide work, analysis thereof helps identify strategies used by workers to overcome problems and achieve goals.

For comprehension and analysis of the prescribed work of the $\mathrm{CHA}$, nine documents were collected, published by the Ministry of Health, and organized into two groups. In the first group, the documents dealt with the work in the Family Health Strategy (FHS) with information about operational guidelines, proposed reorganization of working practices of the teams, and mapping duties of CHA shared with other FHS colleagues. The second group was composed of documents dealing exclusively with the work of the $\mathrm{CHA}$, and the ordinance that regulates the exercise of that profession.

\section{Analysis of CHA tasks}

According to Guerin and colleagues (2001, p. 25), the task is an AE concept pertaining to "a set of objectives given to operators, and a set of prescriptions defined externally to achieve these particular objectives. However, in addition to the explicit task assigned in the prescriptions, and the rules underlining a given work situation, there is also an expected task of what the worker wants to achieve concerning technical and organizational events. The expected task is not always recorded in formal documents (FALZON, 2007).

Therefore, for task analysis, it is necessary to search beyond normative documents, informal records, and perceptions of workers and managers concerning the production goals. It is expected to understand the difference between the explicit task and the expected task, "to prescribe without writing" (FALZON, 2007, p. 9). In this sense, to understand the tasks of the CHA in their different dimensions, a set of procedures were used including document analysis, interviews, and observations. 
In the documental analysis, the work prescriptions of the $\mathrm{CHA}$, described above, together with other documents were included: standard service schedule of eight CHAs, primary care service portfolio, and documents guiding the work of FHS locally as set out in the city of Rio de Janeiro guidelines.

The interviews were conducted with key informants: nurses from family health teams, service managers, and one CHA per team. These semi-structured interviews were guided by scripts, recorded, and transcribed for content analysis. Table 1 details the inclusion criteria for these actors, the objective of the interview, the number of interviews carried out, and the length of time employed in this action.

Table 1. Characteristics of the interviews with key informants

\begin{tabular}{|c|c|c|c|}
\hline Interviewee & Inclusion criteria & Goal & $\begin{array}{l}\text { Recorded } \\
\text { time (h) }\end{array}$ \\
\hline $\begin{array}{l}4 \text { CHAs; } \\
1 \text { per team }\end{array}$ & $\begin{array}{l}\text { distinct teams; } \\
\text { at least one from each team. }\end{array}$ & $\begin{array}{l}\text { To investigate the different } \\
\text { work perspectives related to the } \\
\text { specifics of the team. }\end{array}$ & $4: 30$ \\
\hline 1 manager & $\begin{array}{l}\text { Manager to organize and } \\
\text { evaluate the work of the unit's } \\
\text { professionals. }\end{array}$ & $\begin{array}{l}\text { Check aspects of the general } \\
\text { service organization that } \\
\text { influence the work of the CHA. }\end{array}$ & $1: 52$ \\
\hline $\begin{array}{l}4 \text { nurses; } \\
1 \text { per team }\end{array}$ & $\begin{array}{l}\text { Nurses, along with other } \\
\text { members of the family health } \\
\text { teams, "plan, manage and } \\
\text { evaluate the actions developed } \\
\text { by the CHA" (BRASIL, 2012, } \\
\text { p. 48). }\end{array}$ & $\begin{array}{l}\text { Identify aspects of the } \\
\text { organization of the work of } \\
\text { the CHA, considering the } \\
\text { singularities of each team. }\end{array}$ & $6: 13$ \\
\hline
\end{tabular}

Source: Prepared by the researchers

Observations of tasks established in the standard CHA agenda were also made. Table 2 shows the tasks monitored, the time spent on this observation, and the monitored CHAs. These CHAs are described in numbers to preserve the identities of these professionals. 
Table 2. Observation of the actions developed by the CHA

\begin{tabular}{|l|l|l|}
\hline Assignment & Accompanied subjects & $\begin{array}{l}\text { Total } \\
\text { Observation Time (h) }\end{array}$ \\
\hline Welcome & CHA 1, 2, 3, 6 & $16: 00$ \\
\hline Home visits & CHA 1, 2, 3, 4, 5, 6, 7, 8 & $36: 00$ \\
\hline Staff meeting & Teams A and C & $2: 30$ \\
\hline Unity collegiate meeting & All service members & $3: 00$ \\
\hline Health promotion activity & CHA 6 and 7 & $1: 30$ \\
\hline
\end{tabular}

Source: Prepared by the researchers

\section{Ethical procedures}

The research project was submitted to the Research Ethics Committee of the Hospital Universitário Clementino Fraga Filho, Federal University of Rio de Janeiro, with approval under protocol number: 42680415.5.0000.5257. All data collection procedures were obtained voluntarily, and upon reading and signing the informed consent form by each participant.

\section{Results}

The starting point of the analyses was mapping the CHA's tasks to identify and categorize the actions performed by these professionals. In this sense, the work of the CHA was organized around four categories of actions: four/five turns of home visits (HVs), three shifts of client reception, two shifts of meetings, and one shift dedicated to health promotion actions. We then identified how each of these actions unfolded in the daily work of the CHA. The results are summarized in Table 3, which includes, in addition to the actions previously presented, the data entry of information systems. 
Table 3. The actions developed by CHAs

\begin{tabular}{|c|c|}
\hline Categories & Actions \\
\hline Contact with the population & $\begin{array}{l}\text { Territory design and household count } \\
\text { Population health conditions records } \\
\text { HVs }\end{array}$ \\
\hline Health promotion & $\begin{array}{l}\text { Participation in health education groups } \\
\text { Thematic campaigns }\end{array}$ \\
\hline \multicolumn{2}{|l|}{ User's reception } \\
\hline Local information manager (LIM) & Input health data of their clients into the system \\
\hline Meetings & $\begin{array}{l}\text { Team } \\
\text { General agenda of the unit } \\
\text { Planning health promotion actions }\end{array}$ \\
\hline
\end{tabular}

Source: Prepared by the researchers

Each of the actions listed in Table 3 will be detailed in the following sections. Although these actions are presented in distinct categories, they are subject to overlapping and interdependent between actions of the CHA's daily work.

\section{CHA contact with the population}

In this category, the actions carried out by the CHA were grouped according to the territory they operated, as follows: designation of the territory and registration of families, registration of health conditions in the territory, and HVs. According to the CHA reports, the designation of the territory is the first task performed when implementing a primary health care service, in accordance with the FHS, and it takes place in two stages: delineation of the geographical space covered by the teams and counting households.

The delineation of the coverage area is a physical cut, the mapping of the limits of the territory in which the family health team operates, which must also consider, in addition to the geographical space, other factors: demographic density, geographical barriers, and social vulnerability (RIO DE JANEIRO, 2011). Then, the CHAs count the households to qualify the number of families present in each area, which is not necessarily equivalent to the number of existing homes.

The CHAs reported that is common within the operated territory for several families to share a residence, and therefore they develop strategies for this mapping, 
explained accordingly: "I learned to count the stoves, if you have a stove in the house, it is a family. If there are two stoves, there are two, and so on" (CHA 1).

Bearing in mind that these workers were the first to implement the FHS in the service studied and did not have the possibility of relying on the knowledge of more experienced workers, the strategy developed by CHA 1 highlights its contribution from community knowledge. Thus, if the work of designating the territory allows the CHA to outline the area of his team, this outline gains meaning from the specific knowledge he adds to this process. It also occurs in obtaining reliable data, as the families are more willing to share with CHA's from their territory, and for qualification of the data as CHA's have specific insight of the social, cultural, and family dimensions, that are not easily accessible to other health professionals.

\section{Record of the population's health conditions}

The registration of families in the FHS is done to update the Primary Care Information System (SIAB) which aims to: "get to know the socio-health reality of the population being monitored, evaluate the adequacy of the health services offered - and readjust them, as necessary - and, finally, improve the quality of health services" (BRASIL, 2003, p. 5).

The data are collected from family registration and monitoring forms, and subsequently analyzed through consolidation reports (BRASIL, 2003). It was noted that unlike the task of designating the territory, which had no time constraint, the registration of families takes place continuously as CHAs keep track and respond to the movement of families within their area. It was also found that, according to the demands of the different management levels, new registration data may arise, as shown in the following excerpt:

When the strategy began here, we needed no document on record. Now, the local government requires Natural Persons Register (NPR) of everyone and we had to go obtain it yesterday. It was as though we had to redo all the general registrations just to get the NPR (CHA 1).

The observation made from the registration forms in this research revealed that the CHAs required diverse information of various natures. These questions, denoted as 'completing FORM A', required data collection, such as address, family composition, social issues, and health conditions, illustrating the range of information that $\mathrm{CHAs}$ had to account for during record-keeping. 
In questions related to the social conditions of users, such as education, employment, and family situation, the CHA relied on their own knowledge of the community, as they live in the same territory where they work. However, filling out the data on health issues, the CHA's presented with notable difficulties: on the one hand, they have limited knowledge in the technical field of health; on the other hand, there were countless health issues that needed to be raised according to the highlighted verbalizations.

It is difficult to know everything; about women of childbearing age, smokers, pregnant women, hypertension, diabetes, and even under 2 years old. (CHA 3).

There are things that we know to look for, for instance, when a woman is pregnant, or obese. These are easy. However, it is difficult to know about the oral mucosa and whether a child is malnourished. (CHA 2).

This situation sheds light on how the work of recording the health conditions of the population demands that the CHAs incorporate knowledge exchanged from contact with their teams, such as health-related knowledge, as well as community knowledge as a member of the area where they operate. In this sense, the actions performed outside the health unit, in the CHA's coverage area, creates a different dimension to their work, especially in compliance as an interlocutor between the community and the health services.

The following topic explores the performance of home visits, which is, in turn, a task that combines both the actions related to the registration of users, as well as health surveillance actions, and support for other FHS professionals when entering the territory.

\section{Home visits}

The CHA's duty is to follow-up on all the families under their responsibility through HVs (BRAZIL, 2017), whereas visits should take place with respect to the following stratification risk: a) daily visits to monitor families with people having tuberculosis or leprosy; b) monthly visits to families with people that have either severe hypertension and diabetes, pregnant women, or children up to one year old; c) quarterly visits to families with people that have either mild hypertension and diabetes, children older than two years, or are bedridden (RIO DE JANEIRO, 2011). Families that do not fit into any of these groups should receive at least one annual visit from the CHA. 
In addition to visits that are their exclusive responsibility, CHAs must accompany the HVs of other professionals on the team, especially doctors and nurses. Therefore, the CHA prepares to collect records of cases that have been discussed in a meeting with a developed script. However, at the time of going to the territory, this script can be revised according to the dynamics of each case, as stated:

Go to the priority families first, obtaining all the medical records and then see (...) the most urgent cases, because the less serious ones can be done on another day. For example, nurses visit Tuesday and Friday; on Tuesday, we choose those who will be seen first and then the others are done on Friday (CHA 7).

It was also observed that agents from different areas collaborate, disseminating information that they consider important to prioritize visits:

I live in the heart of the hill, I know what happens there, and then, if I find out about something, I warn the agent that covers this area (CHA 5).

It was found that the HVs show that the CHA needs to deal with issues related to the management of cases, recreating the risk stratification that fits the reality of the population served.

\section{Health promotion actions}

The portfolio of services for primary health care workers in the city of Rio de Janeiro recommends that health promotion includes educational actions aimed at healthy eating, physical activity, and smoking control (RIO DE JANEIRO, 2011). These prescriptions have broad objectives: to promote healthy lifestyles to the ideals of a more inclusive and supportive society, to reduce violence, and to increase social participation for the realization of these purposes. In the realm studied in this research, health promotion actions include education and health promotion groups that address topics such as hypertension and diabetes, prenatal care, childcare, breastfeeding, adolescence, health at school program, combating smoking, and incentives for the practice of physical activity.

Three other actions were identified: campaigns, joint efforts, and commemorative events. The campaigns face health issues that arise as a reality of the service and may have their origins in demands from local management or the Ministry of Health, such as dengue prevention and vaccination. Furthermore, joint efforts are being made to address local problems, such as increasing the coverage of the cervical 
cancer preventive exam. Finally, it was found that on commemorative dates, such as World Diabetes Day, Day of the Anti-Asylum Fight, actions are also carried out.

In health promotion practices, the actions of the $\mathrm{CHA}$ participating in this research were the articulation of spaces in the territory to carry out the actions, dissemination, convening of the target audience, and support for the organization of groups and events.

\section{User's reception}

According to the guidelines of the FHS, the action of client reception refers to managing access to health services aimed at ensuring a more effective service to users, which is the responsibility of all health team professionals serving a family (BRAZIL, 2017). Moreover, documents from the municipality of Rio de Janeiro consider client reception as a clinical guideline, which organizes the service and the work process guaranteeing "qualified, resolutive access, based on the construction of the bond, based on the principle of comprehensive care" (RIO DE JANEIRO, 2011, p. 15).

Thus, it appears that the organization of services, guided by the reception of users, must establish a flow for both meeting scheduled demands and spontaneous demands, which corresponds to the dimension of the first assessment and the identification of users' needs in line with the national policy guidelines (BRASIL, 2017). However, the reception of user models does not end with the flow of users, but also includes the responsibility of the commitment of professionals in search for solutions to the health problems of users in the service and surrounding care network (GOMES; PINHEIRO, 2005).

Regarding the reception of users, this research identified CHAs as the literal frontline of the teams, as they are stationed in stalls located in the reception area of the health unit as the first contact point between the population and the other professionals in the service.

It was observed that the $\mathrm{CHA}$ receives both users with scheduled care and those with spontaneous demand, and screens the cases that arrive according to demand for care as follows:

Before the FHS existed, the user had a culture that, at whatever time he arrives at the health unit, he needed to be attended to. Sometimes it was to receive an examination report: 'he wants to receive the results,' and then we have to explain that it is not the case and that he has to wait for the appointment to be scheduled (CHA 3). 
The CHA can also anticipate the variation in the flow of users according to the agenda, time, or day of the week, as follows:

[...] A day of hypertension and diabetes is more complicated, because it is a day to change protocol since there are a lot of people (CHA 2).

Mondays are bad for everyone because all problems are solved on Mondays. Second, there are also many people who come to ask for a certificate (CHA 3).

From the perspective of the $\mathrm{CHA}$, the user's reception is merely for recording of the attendance and scheduling of consultations - another activity that they perform in the reception bay - mischaracterizing the work in the reception according to these verbalizations:

Is this the work of the CHA? Collecting territory data is the job of the CHA! Reception is not our administrative issue (CHA 2).

Staying in the stall to make an appointment is the receptionist's job” (CHA 2).

Monitoring the work of CHAs in the reception of users allowed the researchers to identify the role they play in the frontline of the health service: screening and qualification of care. Nevertheless, the CHA believes that these activities mischaracterize their role in the FHS and should be carried out by the administrative sector staff or receptionists.

\section{Feeding and handling the LIM}

The local information manager (LIM) integrates various primary care systems unifying the data entry of the population served. Such data help monitor and support the continuous planning of health systems in municipalities. This system has been in use for a long time in the health unit studied in this research and is fed predominantly by $\mathrm{CHAs}$ at two instances: at the reception of users and during the updates of the SSA2 spreadsheet.

SSA2 is a report that synthesizes information collected from FHS to organize the data, as well as the consolidated records and notes made by the CHA throughout the month. According to the accompanying workers, this strategy facilitates this task:

The trick is to keep everything organized, for instance the number of hypertensive patients, the number of this, the number of that, and you keep everything written down, and update it month by month. Things do not change that much. I think only the HVs changed a lot (CHA 4). 
The monitoring of this management sheds light on the fact that although the CHAs are responsible for the inclusion of SSA2 reports in the system with a predetermined deadline, there is no specific schedule on the professionals' agenda for this purpose. Consequently, the recording of data takes place in other activities, as one of the CHAs explains:

We stop doing HVs and leave everything we have to do to register the data in the SSA (CHA 2).

It was found that the lack of equipment available for the number of agents and the precariousness of the system, such as poor internet connectivity, makes it even more difficult to record data in LIM. In view of this, it is evident that the actions undertaken by the CHA to feed this system demand the mobilization of the knowledge they have about the population's health, reducing it to quantitative data. On the other hand, the CHA needs to manage the scarcity of time and the precariousness of the resources needed to achieve the objectives related to this task.

\section{Meetings}

The researchers followed the work of the CHAs in three types of meetings: team, collegiate, and preparing health promotion actions. The team meetings are weekly, and the other meetings are scheduled according to the need.

The participation of CHAs in collegiate meetings is compatible with the participation of other professionals. It was observed that these workers asked their questions regarding the topics discussed, with equal interest and collaboration from others. In meetings aimed at health promotion actions, the CHA was seen as an important mediator between health teams and the community, as an expert on the registered population, and, above all, as a supporter of planned actions.

\section{Discussion}

The work of the CHA has a diversity of logics with contradictions present in the reality of all FHS workers, while literature points out particular implications of this issue in the work performed by these professionals. In this sense, some studies pointed out that the diverse work nature of $\mathrm{CHAs}$ makes it more difficult to delimit their field of action, whether due to the idealization of their work (BARALHAS; PEREIRA, 2011), excessive functions attributed to them (CORIOLANO; LIMA, 
2010; GOMES et al., 2011; PAULA et al., 2015), or the incorporation of tasks that are not necessarily their authority (GOMES et al., 2011; SAKATA; MISHIMA, 2012).

Moreover, the data obtained in this research demonstrated that most of the actions left to the CHA are determined by the needs of the teams or the different levels of management, without considering what is central to their work. This fact creates constraints for CHAs and also corroborates the difficulty of delimiting the scope of their actions. Therefore, the work of the CHA seems to be constantly changing because of new tasks and demands that are insidiously added to their work. In this regard, Ferraz and Aets (2005) state that due to the fluidity in defining their attributions, the CHA often plays the stopgap in FHS services.

This lack of clear boundaries has negative effects on the work of CHAs by necessitating them to cover numerous and varied tasks, making it more difficult to consolidate knowledge and practices that would underpin their professional world. On the other hand, such fluidity has also been considered a positive aspect, as it allows the CHA to build their practices in line with the innovative proposals of UHS and the FHS (GOMES; PINHEIRO, 2005).

Regardless, why is it important to define the professional world of CHAs? Being a worker without a consolidated professional world means that $\mathrm{CHAs}$ are drifting workers, as their tasks can be remodeled at any time. This, in turn, prevents these professionals from building a foundation that can support their actions. Furthermore, the legitimacy of the work of the CHA is constantly at stake, since there is no clarity about what is central.

With this study's analysis, it is possible to distinguish elements that will help in the consolidation of the CHA professional world, such as objects, tools, and values, that shows the interpretations made by these workers to perform the tasks within their existing reality. To identify the object of the CHA's work, we sought the attributions prescribed in normative documents as synthesized in the triad: "to identify signs and situations of risks, guide families and the community, and forward/communicate to the team the cases and situations of risk identified" (TOMAZ, 2002, p. 85). Therefore, from this perspective, the focus of the CHA's activities would be on carrying out HVs and discussing cases with the teams, which is in line with the findings of studies that investigated the work of these agents (TOMAZ, 2002; ALONSO, 2017). 
Concerning the tools and values related to the work of the CHA, it was found that these professionals recognized, as the main tools of the profession, the light care technologies (CORIOLANO; LIMA, 2010; SAKATA; MISHIMA, 2012), and consider the knowledge obtained in contact with families, through $\mathrm{HVs}$, their greatest asset (BARALHAAS; PEREIRA, 2011). In this respect, the results of this research demonstrated that the CHA performs customized and capillary actions that are opposed to the more traditional way of acting in the health field, which, according to Cunha (2005), are predominantly protocol, centered on biological aspects, and operating from the perspective of subjects' immutability.

Therefore, it is the knowledge that the CHA mobilizes from its contact with the population served, which enables the inclusion of data related to the social, family, and cultural order in the sphere of health care. Such knowledge is considered as an important tool not only in carrying out their actions but also in planning the work of family health teams. This was observed in several tasks of the CHA monitored in this research, particularly the HVs and management of the information systems. In the case of $\mathrm{HV}$, the $\mathrm{CHAs}$ perform in addition to the prescribed care actions, the regulation of care, matching the population's health needs, which are not always clear-cut, with the availability of other professionals in their team.

As for the management of information systems, it was found that such systems are important resources for planning local and national health actions. However, despite the relevance of this task, this study evidenced the lack of material resources, such as access to computers and limited internet, and the absence of adequate time in executing this task. This denotes that some tasks left to the CHAs can remain secluded, despite their importance in the operations of the FHS.

Nevertheless, the analysis of the CHA's tasks revealed that among the myriad of actions bequeathed to the $\mathrm{CHA}$, with some related to the triad pointed out by Tomaz (2002) and based on the aforementioned tools and values, many are determined by logic with the distinct natures. To illustrate this situation, the government enforced the feeding of information systems, demanding the registration of NPRs, which also became part of the municipal health management, however, the perception of the CHAs remained that these tasks should be the responsibility of receptionists and is not included in the values of these professionals, as stated in the literature and normative documents. 
Regarding this diversity of actions and logic, it should be noted that this does not concern the typical heterogeneity of the service operation, but highlights the issue that the CHA's tasks are defined based on criteria that originate from different rationalities, often determined in a way that is separate from the values, concepts, and practices, that structure their professional world.

\section{Final considerations}

This research aimed to analyze the CHA's tasks to provide insight that can help in the construction of the professional world of these workers. Thus, first, the study of the CHA's tasks was intended to highlight the professional world of this worker. However, this research has shown that CHAs do not have a set of implicit, conceptual, and practical values, that form a system with the objects of their actions; that is, the professional world of CHA is not fully defined.

This was verified through the identification of the countless functions bequeathed to professionals, who present with different understandings of the dyads: bureaucratic work vs. care work; team demands vs. community demands; epidemiological surveillance vs. singularity of cases; demands of the cases vs. demands of the management.

Although generalization is a fundamental limitation of this study, its results shed light on the power of the CHA's work in the FHS, as well as on the challenges that these workers face in their daily lives. Thus, its main contribution was to generate knowledge about real work situations to support public policy makers and UHS managers in improving the conception of the work of the CHA and FHS.

It is believed that the objective of this research was achieved as, in addition to identifying the countless activities developed by the CHA, the analysis and discussion of the data obtained were able to point out the object, tools and values that should be considered for the consolidation of the professional world of CHA. ${ }^{2}$

\section{References}

ALONSO, C. M. do C. O Trabalho do Agente Comunitário de Saúde na concepção dos projetos terapêuticos singulares na perspectiva dos conceitos mundos profissionais e mundo comum. Rio de Janeiro, 2017. (Doutorado em Engenharia de Produção) - Universidade Federal do Rio de Janeiro, Rio de Janeiro, 2017. 
ARRUDA, C. A. M. et al. O ACS ensina a gente a ter amor pela vida: percepçôes de usuários assistidos na Estratégia Saúde da Família no Ceará. Revista Bahiana de Saúde Pública. v. 34, n. 4, p. 935-950 out-dez. 2010.

BARALHAS, M.; PEREIRA, M. A. O. Concepçôes dos agentes comunitários de saúde sobre suas práticas assistenciais. Physis, Rio de Janeiro, v. 21, n. 1, p. 31-46, 2011. Disponível em: http://www.scielo.br/scielo.php?script=sci_arttext\&pid=S0103-73312011000100003\&lng=en \&nrm=iso>. Acesso em: 1 jan. 2016.

BINDA, J.; BIANCO, M. de F.; SOUSA, E. M. de. O trabalho dos agentes comunitários de saúde em evidência: uma análise com foco na atividade. Saúde Soc., São Paulo, v. 22, n. 2, p. 389-402, 2013. Disponível em: http://www.scielo.br/pdf/sausoc/v22n2/v22n2a11.pdf. Acesso em: 20 jun. 2019.

BRASIL. Ministério da Saúde. Secretaria de Atenção à Saúde. Departamento de Atenção Básica. SIAB: Manual do Sistema de Informação de Atenção Básica. Brasília: Ministério da Saúde, 2003.

BRASIL. Portaria no 2.436, de 21 de setembro de 2017. Aprova a Política Nacional de Atenção Básica, estabelecendo a revisão de diretrizes para a organização da Atenção Básica, no âmbito do Sistema Único de Saúde (SUS). Diário Oficial da União. Brasília, 22 ago. 2017.

BUCCIARELLI, L. L. Reflective Practice in Engineering Design. Design Studies. v. 5, n. 3, p. 185-190, 1984.

BÉGUIN, P. Conduite de projet et fabrication collective du travail: une approche développementale. Habilitação para dirigir pesquisas. Ecole Doctorale: Sciences Sociales. Universiade Victor Segalen Bordeaux 2. Bordeaux: França. 2010.

BÉGUIN, P. O ergonomista, ator da concepção. In: FALZON, Pierre (ed.). Ergonomia. São Paulo: Editora Blucher, 2007. p. 317-330.

BRITO, J. et al. O trabalho nos serviços públicos de saúde: entre a inflaçáo e a ausência de normas. In: _-__-_. Trabalhar na saúde: experiências cotidianas e desafios para a gestão do trabalho e do emprego. Editora Fiocruz, 2011. p. 23-43.

BUCCIARELLI, L. L. An ethnographic perspective on engineering design. Design Studies, v. 9, n. 3, p. 159-168, jul. 1988. Disponível em: <http://www.sciencedirect.com/science/article/ pii/0142694X88900452>. Acesso em: 21 mar. 2015.

CORIOLANO, M. W. de L.; LIMA, L. S. de. Grupos focais com agentes comunitários de saúde: subsídios para entendimento destes atores sociais. Rev. enferm. UERJv. 18, n. 1, p. 92-96, jan-mar. 2010. Disponível em: http://www.facenf.uerj.br/v18n1/v18n1a16.pdf. Acesso em: 1 jan. 2016.

CUNHA, G. T. A construção da clínica ampliada na atenção básica. São Paulo: Hucitec, 2005.

DANIELLOU, F.; LAVILLE, A.; TEIGER, C. Ficção e realidade do trabalho operário. Revista Brasileira de Saúde Ocupacional, v. 17, n. 68, p. 7-13, 1989. 
FALZON, P. Natureza, objetivos e conhecimentos da ergonomia. In: FALZON, Pierre (ed.). Ergonomia. São Paulo, Editora Blucher, 2007. p. 3-19.

FERRAZ, L.; AERTS, D. R. G. de C. O cotidiano de trabalho do agente comunitário. Ciência \& Saúde Coletiva, p. 347-355, 2005.

GALAVOTE, H. S. et al. Alegrias e tristezas no cotidiano de trabalho do agente comunitário de saúde: cenários de paixōes e afetamentos. Interface Comunicação Saúde Educação, v. 17, n. 46, p. 575-586. 2013. Disponível em: http://www.scielo.br/pdf/icse/2013nahead/aop2213.pdf. Acesso em: 1 jan. 2016.

GOMES, A. de L. et al. O elo entre o processo e a organização do trabalho e a saúde mental do Agente Comunitário de Saúde na Estratégia Saúde da Família no município de João Pessoa Paraíba - Brasil. Revista Brasileira de Ciências da Saúde. v. 15, n. 3, 2011. Disponível em: http:// periodicos.ufpb.br/ojs2/index.php/rbcs/article/viewFile/10564/6816. Acesso em: 1 jan. 2016.

GOMES, M. C. P. A.; PINHEIRO, R. Acolhimento e vínculo: práticas de integralidade na gestão do cuidado em saúde em grandes centros urbanos. Interface (Botucatu), v. 9, n. 17, p. 287301, ago. 2005. Disponível em: <http://www.scielo.br/scielo.php?script=sci_arttext\&pid=S141432832005000200006\&lng=en\&nrm=iso>. Acesso em: 10 fev. 2015.

GUÉRIN, F. et al. Compreender o trabalho para transformá-lo. São Paulo: Blucher, 2001.

NOUROUDINE, A. Como conhecer o trabalho quando o trabalho não é mais o trabalho? Trab. educ. saúde, v. 9, n. supl. 1, p. 69-83, 2011.

OLIVEIRA, D. T. et al. Percepçóes do Agente Comunitário de Saúde sobre sua atuação na Estratégia Saúde da Família. Cogitare Enfermagem. v. 17 n. 1, p. 132-137, jan./mar. 2012. Disponível em: http://revistas.ufpr.br/cogitare/article/view/26386/17580. Acesso em: 1 mar. 2015.

PAULA, I. R. et al. Capacidade para o trabalho, sintomas osteomusculares e qualidade de vida entre agentes comunitários de saúde em Uberaba, Minas Gerais. Saúde Soc. São Paulo, v. 24, n. 1, p.152-164, mar. 2015. Disponível em: http://www.scielo.br/pdf/sausoc/v24n1/0104-1290sausoc-24-1-0152.pdf. Acesso em: 20 jun. 2019.

RIO DE JANEIRO. Secretaria Municipal de Saúde e Defesa Civil. Superintendência de Atenção Primária. Guia de Referência Rápida. Carteira de Serviços: Relação de serviços prestados na Atenção Primária à Saúde. Rio de Janeiro: SMSDC, 2011. (Série F. Comunicação e Educação em Saúde).

SAKATA, K. N.; MISHIMA, S. M. Articulação das açóes e interação dos Agentes Comunitários de Saúde na equipe de Saúde da Família. Revista da Escola de Enfermagem da USP, Sáo Paulo, v. 46, n. 3, p. 665-672, jun./2012. Disponível em: http://www.scielo.br/scielo.php?pid=S008062342012000300019\&script=sci_abstract\&tlng=pt. Acesso em: 21 mar. 2015. 
TOMAZ, J. B. C. O agente comunitário de saúde não deve ser um "super-herói". Interface (Botucatu), v. 6, n.10, fev. 2002. Disponível em: <http://www.scielo.br/scielo.php?script=sci_ arttext\&pid=S1414-32832002000100008\&lng=en\&nrm=iso>. Acesso em: 14 maio 2013.

\section{Notes}

${ }^{1}$ Funding: Coordination for the Improvement of Higher Education Personnel (CAPES - Process BEX 5217/2014-08 Program CAPES-COFECUB 702/11).

${ }^{2} \mathrm{C}$. M. C. Alonso conceived the research project, performed data analysis, and participated in the writing, review, and approval of the final version of the manuscript. F. J. C. M. Duarte guided the data collection and analysis and participated in the review of the final version. V. Pueyo guided the data analysis and participated in the review, and approval of the final version. P. D. Béguin conceived the research project, guided the construction of the theoretical framework and data analysis, and participated in the writing and approval of the final version of the manuscript. 


\section{Resumo}

Agente comunitário de saúde: um mundo profissional em busca de consolidação

A contribuição do trabalho dos ACS tem sido apontada como estratégica para superação do modelo biomédico de produção de saúde. No entanto, fragilidades na delimitação dessa profissão impóem contradiçôes e impedimentos a esse trabalho, dificultando a construção do mundo profissional dos ACS. Este artigo tem como objetivo analisar as tarefas realizadas pelos ACS no intuito de revelar objeto, valores e ferramentas usadas por esses trabalhadores que ajudem na consolidação do seu mundo profissional. Trata-se de pesquisa qualitativa norteada pelos princípios da Ergonomia da Atividade, que contou com análise documental, observaçóes sistemáticas e entrevistas. Os resultados demonstraram que em virtude de distintas e inúmeras atividades executadas pelos ACS, o mundo profissional desses trabalhadores não está plenamente delineado. Contudo, acredita-se que o resultado, análise e discussão dos dados apurados nesta pesquisa são capazes de apontar elementos que servem para apoiar a consolidação do mundo profissional dos ACS.

> Palavras-chave: Ergonomia; Atenção Primária à Saúde; trabalho em equipe multiprofissional. 